\title{
Genotypic performance, character correlations and path analysis of pod yield in Abelmoschus caillei (A. Chev.) Stevels
}

\author{
Christopher O. Alake, Omolayo J. Ariyo, Moninuola A. Ayo-Vaughan \\ Department of Plant Breeding and Seed Technology, University of Agriculture, Abeokuta, Ogun \\ State, Nigeria
}

\begin{abstract}
Direct selection based on pod yield is often a problem in West African okra (Abelmoschus caillei (A. Chev.) Stevels) breeding programs. Information on inter-relationships among traits to implement indirect selection for pod yield is needed. Objectives of this study were to evaluate the performance of West African okra varieties in two cropping seasons prevailing in Nigeria, and to determine the associations among main agronomic characters and their influence on pod yield. Twenty-five genotypes were grown in two planting seasons at the Research Farm of the Federal University of Agriculture, Abeokuta in 2008-2009 using a randomized complete-block design with three replications. Sixteen plant characters were measured. The data were subjected to variance, correlation and path analyses. Four genotypes, viz., CEN 010, CEN 012, NGAE-96-04 and AGA 97/066-5780 demonstrated potential for high pod yield. CEN 012 and AGA 97/066-5780 in addition, demonstrated early flowering higher number of pods. Character associations varied between planting seasons. The dependence of pod yield on final plant height, number of branches per plant, number of pods per branch, number of pods per plant, number of ridges per pod, weight of 250 seeds, pod length and seed weight per plant was noted in both
\end{abstract}

Correspondence: Dr. Christopher 0. Alake, Department of Plant Breeding and Seed Technology, University of Agriculture, P.M.B 2240, Abeokuta, Ogun State, Nigeria. Tel. +234.8066693657. E-mail: alakeco@unaab.edu.ng

Key words: correlation, path analysis, pod yield, varietal performance, West African okra.

Acknowledgments: the study was part of Ph.D. thesis entitled Diversity, Genetic analysis and Stability of performance of West African okra, Abelmoschus caillei (A.Chev) Stevels. The help received from the National Center for Genetic Resource and Biotechnology (NACGRAB) and Centre for Environment, Renewable Natural Resources Management, and Development (CENRAD), Ibadan, Oyo-State, Nigeria for providing West African okra germplasms for the study is gratefully acknowledged.

Received for publication: 19 May 2012.

Accepted for publication: 11 October 2012.

(C) Copyright C.O. Alake et al., 2012

Licensee PAGEPress, Italy

Italian Journal of Agronomy 2012; 7:e44

doi:10.4081/ija.2012.e44

This article is distributed under the terms of the Creative Commons Attribution Noncommercial License (by-nc 3.0) which permits any noncommercial use, distribution, and reproduction in any medium, provided the original author(s) and source are credited. planting seasons. In both seasons, number of pods per plant exhibited a high positive direct effect on pod yield. In conclusion, the trait of most interest for improving pod yield under early and late-season conditions was number of pods per plant.

\section{Introduction}

West African okra, Abelmoschus caillei (A. Chev.) Stevels is an unconventional okra type. It is grown mainly for its edible immature pods in the tropics, but in most African countries young leaves and seeds are consumed and, where the young leaves are often picked as vegetables, they are at least as important as the fruiting pods in Nigeria (Olasantan and Salau, 2007). It is taller and has bigger pods than the conventional type, Abelmoschus esculentus (L) Moench, and is essentially photoperiod sensitive. It is annual but can grow vegetatively under long-day conditions, and it is relatively tolerant to diseases and insect pests. The production of West African okra is influenced by the length of the daytime period. Regardless of the time of planting, most West African okra varieties remain vegetative until the daylight period falls below 12.5 hours. It is estimated that 500,000-600,000 tons of okra are produced annually in West and Central Africa, with West African okra making up half of this amount (Grubben and Denton, 2004). In Nigeria, about 455,100 hectares of land is under okra cultivation, with a mean yield of $2100 \mathrm{~kg} /$ hectare (FAOSTAT, 2010).

Maximizing crop yield for a particular region via agronomy and/or plant breeding requires the agro-morphology of crop to be well adapted to the available resources and constraints in the production environment (Shorter et al., 1991). Loss and Siddique (1994) regarded early flowering as an important characteristic for high yield in a shortseason, late cropping-type environment. Wide variation in the agromorphology of West African okra has been reported (Ariyo, 1993; Adeniji and Aremu, 2007) and further improvement in West African okra could be achieved by selecting for early flowering and early maturing varieties. Such varieties must necessarily have a good combination of the required agro-morphological characters to cope with fluctuating weather conditions experienced in this region; and their earliness may enable farmers to grow a second crop within a stipulated period. Wilson (1981) pointed out that selection for physiological and morphological traits could lead to increased plant biomass needed to convert assimilate to economical product within the plant and to alleviate or avoid environmental constraints. Although increased biomass might be expected to result in increased economic yield; in practice, this is not always the case (Goldsworthy, 1970).

In most species, yield is influenced by several characters that affect plant growth throughout the planting season. Analysis of yield components can help explain how yield losses occur (Gardner et al., 1985). On the other hand, attempts to increase pod yield in okra by increasing pod number or pod mass have been somewhat unsuccessful 
because of compensation occurring between these components (Adeniji and Aremu, 2007).

When establishing associations between pod yield and yield components, correlation analysis is a useful tool, as it provides an indication of the degree of association between two variables, which are considered to be interdependent (Gomez and Gomez, 1984; Sokal and Rohlf, 1995; Steel et al., 1997; Sood et al., 1993). However, associations detected from correlation coefficients may not necessarily be attributed to a single variable but rather to a number of interdependent variables. Therefore, decisions based solely on correlation coefficients may not necessarily be reliable, as only limited information is revealed about what may necessarily be a complex series of interrelationships among variables (Kang, 1994). Information on correlation may be further partitioned into direct and indirect effects for a given set of relationships (Gravois and Helms, 1992). Path analysis is an important analytical tool, which has been, or can be, used to quantify a perceived biological relationship through partitioning of correlation coefficients into direct and indirect effects (Condon, 2004). If an indirect relationship exists between two variables, path analysis can help elucidate to what extent other variables are involved or affect the relationship (McGiffen $e$ al., 1994). Using path analysis, the variables contributing most to an observed relationship can be identified and employed in formulating an effective selection strategy.

In Nigeria, progress in okra breeding has been achieved by selecting for varieties with high pod yield using character correlations. In a study, Adeniji and Aremu (2007) showed that pod yield in a number of West African okra varieties was influenced chiefly by plant height at maturity, number of ridges per pod, number of pods per plant, mature pod length and number of seeds per ridge. Rashwan (2011) reported that pod yield in okra had a positive and significant association with number of fruits per plant, number of branches per plant and fruit diameter. The previous investigations provided useful information for exploring in depth varietal performance and character correlations in A. caillei. However, challenges still exist because of a lack of information to establish a general standard for the selection and improvement of $A$. caillei. Therefore, this investigation sought:

i) to evaluate selected West African okra cultivars for their agronomic performance and pod yield in two different planting seasons;

ii) to elucidate the association between pod yield and its components in West African okra.

\section{Materials and Methods}

\section{Germplasm collection}

A total of 25 West African okra genotypes were used in this study. These comprised 13 varieties from the gene bank of National Centre for Genetic Resources and Biotechnology (NACGRAB), Ibadan, Nigeria; eight varieties from Centre for Environment, Renewable Natural Resources Management, and Development (CENRAD), Ibadan, Nigeria; and four varieties from several locations in Ekiti and Ondo states within the southern area of Nigeria, which fall within the Tropical Rain Forest and Savannah Transition (Table 1).

Table 1. Code names, source and specific morphological characters of the accessions used.

\begin{tabular}{|c|c|c|c|c|c|c|c|}
\hline S/N & $\begin{array}{l}\text { Genotype Code } \\
\text { Names }\end{array}$ & Source & Stem colour & Stem pubescence & Pod colour & Pod pubescence & Pod position \\
\hline 1. & CEN 010 & CENRAD & $\mathrm{LP}$ & Glabrous & DG & Downy & Erect \\
\hline 2. & NGAE-96-012-2 & NACGRAB & Purple & Conspicuous & LG & Pricky & SE \\
\hline 3. & NGAE-96-012-3 & NACGRAB & Green & Glabrous & GwR & Downy & SE \\
\hline 4. & CEN 016 & CENRAD & Purple & SP & DG & Prickly & SE \\
\hline 5. & CEN 012 & CENRAD & Purple & Conspicuous & Green & Prickly & Horizontal \\
\hline 6. & CEN 007 & CENRAD & Green & Glabrous & YwG & Downy & SE \\
\hline 7. & NGAE-96-04 & NACGRAB & Green & Glabrous & Green & SP & SE \\
\hline 8. & CEN 015 & CENRAD & LP & Glabrous & DG & Downy & SE \\
\hline 9. & OАA96/175-5328 & NACGRAB & Green & SP & DG & Prickly & Horizontal \\
\hline 10. & AGA97/066-5780 & NACGRAB & Purple & Glabrous & DG & Downy & Horizontal \\
\hline 11. & ADO-EKITI-1 & Ekiti state & Green & Glabrous & DG & Prickly & Horizontal \\
\hline 12. & CEN 001 & CENRAD & Purple & Glabrous & $\mathrm{GwY}$ & Prickly & Horizontal \\
\hline 13. & CEN 009 & CENRAD & LP & Glabrous & Green & Downy & Horizontal \\
\hline 14. & NGAE-96-0062-2 & NACGRAB & Purple & Glabrous & Green & Downy & Horizontal \\
\hline 15. & NGAE-96-0066 & NACGRAB & Purple & Glabrous & Green & SP & Horizontal \\
\hline 16. & NGAE-96-0061 & NACGRAB & LP & Glabrous & GwR & SP & SE \\
\hline 17. & NGAE-96-0060 & NACGRAB & Purple & Glabrous & Green & Downy & Horizontal \\
\hline 18. & NGAE-96-0064 & NACGRAB & PwG & SP & GwR & Prickly & Horizontal \\
\hline 19. & NGAE-96-0063 & NACGRAB & $\mathrm{DR}$ & SP & Green & Prickly & Erect \\
\hline 20. & CEN 005 & CENRAD & GwP & Glabrous & YG & SP & Horizontal \\
\hline 21. & NGAE-96-0065 & NACGRAB & PwG & Glabrous & Green & Downy & Horizontal \\
\hline 22. & OJA OBA-2 & Ondo state & Green & Glabrous & YG & SP & Horizontal \\
\hline 23. & OJA OBA-3 & Ondo state & Green & Glabrous & Green & SP & Erect \\
\hline 24. & ADO-EKITI-3 & Ekiti state & Purple & Glabrous & Green & Downy & SE \\
\hline 25. & NGAE-96-0067 & NACGRAB & GwP & Glabrous & GwR & SP & Horizontal \\
\hline
\end{tabular}

LG, light green; GwP, green with purple; PwG, purple with green; DG, dark green; LP, light purple; GwR, green with red; YG, yellowish green; GwY, green with yellow; DGwR, dark green with red; SP, slightly prickly; SE, semi-erect. 


\section{Experimental site}

The field trials were conducted during early and late planting seasons of the year 2008-09 at the Teaching and Research Farm of the Federal University of Agriculture, Abeokuta (FUNAAB), Nigeria.Geographically, FUNAAB is situated in the derived savanna zone on latitude $7^{\circ} 9^{\prime} \mathrm{N}$ and the longitude $3^{\circ} 21^{\prime} \mathrm{E}$. Climatologically, FUNAAB experiences approximately seven months (March-September) of bimodal rainfall pattern that peaks in June and September with a short dry spell in August and a long dry spell in November-March. The early cropping season is from March toJuly with a long day length while the late season is from September to November with a short day length (Table 2). The soil of the experimental site is classified as an underlain basement complex rock with quartz schist, coarse grained and fine grained granite and gneiss as parent material (Aiboni, 2001), with a pH ranging from 5.5-6.5.

\section{Methodology}

For early planting season, land preparation was done by tractor ploughing and harrowing with pulverization and leveling done manually under upland environment, while manual land preparation was done for the late planting season trial under hydromorphic environment. The early season planting, was done in July, 2008 and late season planting in December, 2008. The experiment was a randomized complete block with three replications in each of the two seasons in a single row plot. Thirty-six seeds were planted in 6 m-long plot on 15 July, 2008 (early planting season) and on 6 December, 2008 (late planting season) with plant spaced $1 \mathrm{~m}$ and between-plant distance within a row was $0.6 \mathrm{~m}$. Plots were thinned to one plant per hill at the-first-true leaf stage giving 12 plants per row and data were taken on 10 competitive plants within each row leaving the two border plants for border effects. Weeding was carried out manually 3 weeks after planting and as necessary to keep the plots weed-free. Following thinning, fertilizer application of a compound fertilizer in the form of NPK 20:10:10 was applied by drilling at the recommended rate of $60 \mathrm{~kg} / \mathrm{ha}$ to support crop growth.

At each site, Cypermethrin (Cymbush at the rate of $50 \mathrm{~mL} / 10 \mathrm{~L}$ of water) was applied 4 weeks after planting (WAP) and subsequently fortnightly. Pyrethroid (karate EC) was applied twice during the reproductive phase at $20 \mathrm{~mL} / 15 \mathrm{~L}$ to reduce the insect damage on the crop. The fruits collected per experimental row had their seeds extracted and air dried.

\section{Data collection and analysis}

During the course of the study, 16 agro-morphological traits were measured. Traits studied usually considered important are yield and yield components in addition to other agronomic traits in West African okra. These included: number of days to flowering; plant height at flowering; number of leaves per plant; number of branches per plant; number of pods on the branches; number of pods on the main stem; number of pods per plant; mature plant height; length of mature pod; width of mature pod; number of ridges per pod; number of seeds per ridge; number of seeds per pod; 250 seed weight; seed weight per plant; and mature pod yield per plant.

Number of days to flowering trait was calculated by counting days from the date of the planting beginning to the day of opening of the $50 \%$ of the flowers in a row. Plant height at flowering $(\mathrm{cm})$ trait was measured from the soil level base of the plant to the main stem termination of flowering in a row. Number of leaves at flowering trait was also calculated. Number of branches/plant trait was calculated by counting the branches on the main stem; number of pods at the branches and number of pods on the main stem traits were calculated by counting the pods on the branches and main stem; mature plant height $(\mathrm{cm})$ trait was measured from the soil level base of the plant to the main stem termination at harvest; length of mature pod $(\mathrm{cm})$ trait was measured from the tip of the pod to the attachment of the pedicle. Width of mature pod $(\mathrm{cm})$ trait was measured as the widest circumference of the mature harvested pods, number of ridges/pod trait was determined at maturity by counting the number ridges in ten randomly selected pods and averaging over ten, number of seeds/ridge trait was determined at maturity by counting the number of seeds in each of the ridges of ten randomly picked pods and dividing by the total number of ridges in the ten pods, 250 seed weight (g) trait was calculated by weighing of randomly selected seeds, seed weight per plant (g) trait was calculated by weighing the bulked dried seeds of sampled plant divided by 10 , pod yield per plant (g) trait was calculated by weighing of average value of the total weight of mature harvested pods from sampled plant. Traits calculated from these data were number of seeds/pod and number of pods per plant determined as:

\section{Seed/pod=seed/ridge $\mathrm{x}$ ridge/pod}

Number of pods/plant $=$ number of pods at stem + number of pods at branches seeds respectively.

Dried pods that have turned brown within the row were harvested manually in December and May for early and late planting seasons, respectively, to determine mature pod yield per plant and latter seed weight after seed extraction and drying. Data on the 16 agronomic and morphological traits were recorded for two years after harvest.

\section{Statistical analysis}

The mean trait values were used for statistical analysis. Pooled data of the two years were analyzed for variance components (Snedecor and Cochran, 1980) to determine the significant differences among varieties for the investigated plant characters. Where significant means were found, they were compared using Duncan's multiple range test at $5 \%$ level (SAS, 2000). Secondly, separately for each planting season, relationships among variables (i.e. 16 traits) for the 25 genotypes of West African okra were investigated using phenotypic and genotypic correlations calculated from the mean values of the genotypes using the procedure outlined by Miller et al. (1958). Genetic $\left(\mathrm{r}_{\mathrm{g}}\right)$ and phenotypic $\left(r_{p}\right)$ correlations between pairs of traits were estimated as described by Kempthorne (1973). Also, for each planting season the

Table 2. Rainfall, temperature, relative humidity and wind run (mean of 2000-09)* at experimental site, Abeokuta, Nigeria.

\begin{tabular}{|c|c|c|c|c|c|c|c|c|c|c|c|c|}
\hline Weather data & Jan & Feb & Mar & Apr & May & Jun & Jul & Aug & Sep & Oct & Nov & Dec \\
\hline Rainfall (mm) & 2.3 & 15.9 & 33.5 & 69.0 & 70.4 & 134.6 & 87.7 & 55.0 & 107.3 & 46.7 & 12.2 & 2.5 \\
\hline $\begin{array}{l}\text { Temperture }\left({ }^{\circ} \mathrm{C}\right) \\
\text { Maximum } \\
\text { Minimum }\end{array}$ & $\begin{array}{c}32.22 \\
21.9\end{array}$ & $\begin{array}{l}33.2 \\
23.6\end{array}$ & $\begin{array}{l}33.3 \\
24.2\end{array}$ & $\begin{array}{l}32.1 \\
23.9\end{array}$ & $\begin{array}{l}29.5 \\
22.2\end{array}$ & $\begin{array}{l}28.0 \\
21.8\end{array}$ & $\begin{array}{l}28.8 \\
22.8\end{array}$ & $\begin{array}{l}27.6 \\
22.4\end{array}$ & $\begin{array}{l}26.6 \\
20.2\end{array}$ & $\begin{array}{l}30.5 \\
22.9\end{array}$ & $\begin{array}{l}32.2 \\
20.7\end{array}$ & $\begin{array}{l}31.8 \\
22.7\end{array}$ \\
\hline Relative humidity (\%) & 60.5 & 65.6 & 69.4 & 72.4 & 81.7 & 72.2 & 79.9 & 83.0 & 72.9 & 77.8 & 74.1 & 68.1 \\
\hline Wind run km/day(h) & 14.1 & 15.5 & 64.7 & 18.1 & 16.3 & 11.6 & 12.6 & 15.0 & 17.4 & 17.7 & 2.8 & 3.1 \\
\hline
\end{tabular}

*Department of Agrometrology and Water Resources Management, Federal University of Agriculture, Abeokuta, Nigeria. 
relationship between pod yield and its components (five traits) were investigated using the path coefficient technique as outlined by Dewey and $\mathrm{Lu}$ (1959). Multiple linear regressions was used to calculate the path coefficients to establish direct correlations and hypothesize relationships (McGiffen et al., 1994) between pod yield and yield related characters. Pod yield was considered to be dependent variable, while its components $(\mathrm{Xn})$ i.e. number of pods at branches $\left(\mathrm{X}_{1}\right)$, number of pods at stem $\left(X_{3}\right)$, number of pods per plant $\left(X_{4}\right)$ and seed weight per plant $\left(\mathrm{X}_{5}\right)$ were considered to be independent variables. Standardized partial regression coefficients from regression analysis were used as path coefficients for the respective independent variables. The indirect effects were determined by multiplying the correlation by their respective path coefficients. For the normal equation hypothesized for path analysis, $P_{i j}$ represents path coefficients and $r_{i j}$ represents simple correlation coefficients. Each normal equation partitions the simple correlation into direct and indirect effect.

The simultaneous equations ( $\mathrm{n}-1$ for 6 traits) for calculating direct effect of each of five traits (1 to 5) on trait number 6 are as follows:

$$
\begin{aligned}
& P_{16}+r_{12} P_{26}+r_{13} P_{36}+r_{14} P_{46}+r_{15} P_{56}=r_{16} \\
& r_{12} P_{16}+P_{26}+r_{23} P_{36}+r_{24} P_{46}+r_{25} P_{56}=r_{26} \\
& r_{13} P_{16}+r_{23} P_{26}+P_{36}+r_{34} P_{46}+r_{35} P_{56}=r_{36} \\
& r_{14} P_{16}+r_{24} P_{26}+r_{34} P_{36}+P_{46}+r_{45} P_{56}=r_{46} \\
& r_{15} P_{16}+r_{25} P_{26}+r_{35} P_{36}+r_{45} P_{46}+P_{56}=r_{56}
\end{aligned}
$$

In the above equations $r_{i j} s$ represents correlation coefficients between $i$ th and $j$ th traits ( $\mathrm{j}=1$ to 5 , and $j=2$ to 6 ), and $\mathrm{P}_{\mathrm{i} 6}$ represent direct effect of $i$ th trait on trait number 6

Residual effect is computed as:

$\left[1-\mathrm{P}_{16}{ }^{2}+\mathrm{P}_{26}{ }^{2}+\mathrm{P}_{36}{ }^{2}+\mathrm{P}_{46}{ }^{2}+\mathrm{P}_{56}{ }^{2}+2 \mathrm{r}_{12} \mathrm{P}_{16} \mathrm{P}_{26}+2 \mathrm{r}_{13} \mathrm{P}_{16} \mathrm{P}_{36}+2 \mathrm{r}_{14} \mathrm{P}_{16} \mathrm{P}_{46}\right.$ $+2 \mathrm{r}_{15} \mathrm{P}_{16} \mathrm{P}_{56}+2 \mathrm{r}_{23} \mathrm{P}_{26} \mathrm{P}_{36}+2 \mathrm{r}_{24} \mathrm{P}_{26} \mathrm{P}_{46}+2 \mathrm{r}_{25} \mathrm{P}_{26} \mathrm{P}_{56}+2 \mathrm{r}_{34} \mathrm{P}_{36} \mathrm{P}_{46}+2 \mathrm{r}_{35} \mathrm{P}_{36}$ $\left.\mathrm{P}_{56}+2 \mathrm{r}_{45} \mathrm{P}_{46} \mathrm{P}_{56}\right]$

The partitioning displayed diagrammatically is the sum of the direct effect plus indirect effect on the pod yield (Figure 1).

\section{Results and Discussion}

The results of the combined variance analysis of agro-morphological traits and seasonal means in 25 West African okra varieties used in this study are presented in Table 3 . There were statistically significant $(\mathrm{P}<0.01)$ differences within the two seasons for all the agro-morphological traits with the exception of number of pods per branch. This may be attributed to diverse genetic background of the genotypes studied, which implies that in a population of West African okra genotypes, there is an opportunity to select desirable genotypes with increased pod yield component characters which may be able to perform well and give increased yield. This corroborates the conclusion of Ariyo (1993) that genetic variability among the West African okra accessions proved to be large. Generally, contributions of genotype $\mathrm{x}$ season interactions were lower than those of genotype. The statistically significant $(\mathrm{P}<0.01)$ genotype $\mathrm{x}$ season interactions observed for all the traits with the exception of number of pods per branch, 250 seed weight, pod length and pod breadth indicated that it is difficult for breeders to decide which genotypes should be selected that show a positive genetic response in term of pod yield improvement, as reported here. This further supports the need for stable and high yielding varieties for farmers in Nigeria who use no or limited input to grow West African okra under harsh and unpredictable environments. This agrees with similar observations by Ariyo and Ayo-Vaughan (2000) on Abelmoschus esculentus. The fact that season and genotypic variances were significant for most of the characters is an indication that variable factors associated with seasons such as amount of rainfall, solar radiation, temperature and wind speed are important. In the two seasons, the rainfall was inadequate in terms of distribution and cessation. For example, average values of rainfall of a polyannual period of ten years during the flowering stage for early and late planting seasons were 107.3 and 15.9 $\mathrm{mm}$, respectively. The maximum and minimum temperatures were higher during the late season planting of November-April when compared with the other months. However, relative humidity values during the same period ranged from 60.5 to $74.1 \%$. The wind run is significantly higher in the month of March compared to the other months of the year (Table 2). The variation in the weather conditions, along with the diversity of cultivars resulted in non-uniform performance across the seasons, which is evidenced in a great variation among the agronomic and morphological traits.

In Tables 4 and 5 are presented the mean of measured traits in 25 varieties of West African okra studied, using Duncan multiple range test for mean comparison in the early and late planting seasons. In the early planting season pod yield per plant ranged from $18.4 \mathrm{~g}$ for genotype 0AA 96/175-5328 to $79.8 \mathrm{~g}$ for genotype CEN 010 while seed weight per plant varied from $12.7 \mathrm{~g}$ for NGAE-96-0062-2 to $32.1 \mathrm{~g}$ for genotype NGAE-96-0060. Ado-Ekiti-3 flowered earlier (94.5) than all others, followed by NGAE-96-012-2 (95.9) and NGAE-96-012-3 (96.2). The latest flowered genotype was $0 \mathrm{ja}-\mathrm{Oba}-2$ (103.0). Final plant height ranged from $129.3 \mathrm{~cm}$ for CEN-015 to $222.8 \mathrm{~cm}$ for 0ja-Oba-2. The highest number of pods per plant was recorded for AGA 97/066-5780 (16.4) followed by NGAE-96-0067 (15.2) and NGAE-96-0063 (15.2) whilethe lowest was recorded for CEN016 (4.5).In the late planting season, genotype NGAE-96-04 exhibited the highest mean value for mature pod yield of $63.8 \mathrm{~g}$ and OAA 96/175-5328 had the lowest mature pod yield of $14.0 \mathrm{~g}$. The seed weight per plant varied among the genotypes with NGAE-9604 having largest weight of $32.8 \mathrm{~g}$ while CEN 001 had the smallest

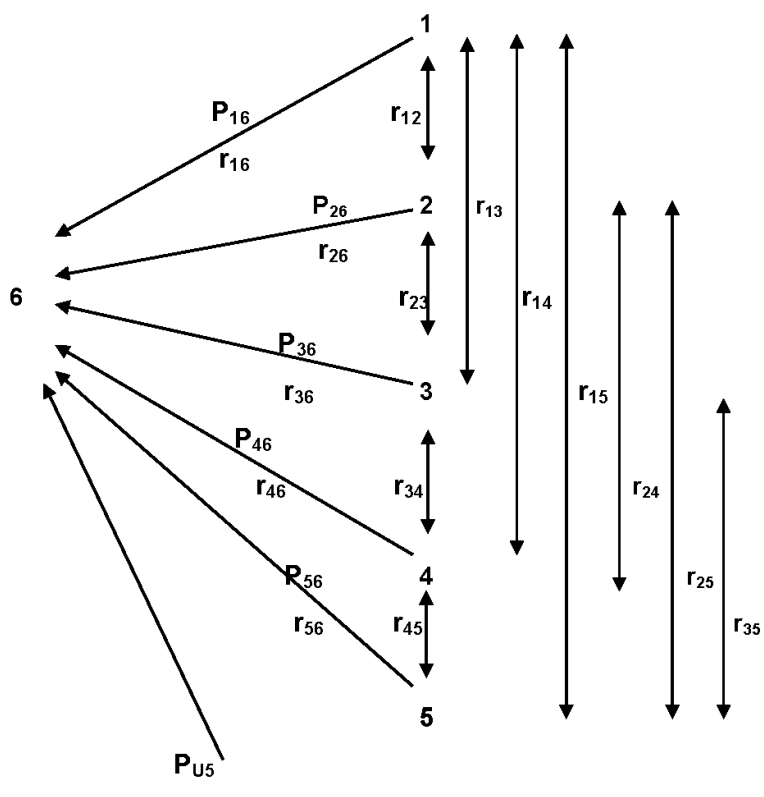

$\mathbf{U}_{\text {(Residual) }}$

Figure 1. Path coefficient diagramme showing direct and indirect effects of five characteristics of West African okra on pod yield. The double arrowed lines indicate correlation between two variables and the single arrowed lines represent direct influence as measured by path coefficient. 
Table 3. Variance analysis and seasonal means of pod yield and yield-related components in 25 West African okra varieties evaluated in early and late planting seasons in South-Western Nigeria.

\begin{tabular}{|c|c|c|c|c|c|c|c|}
\hline \multirow{2}{*}{ Character } & \multirow[t]{2}{*}{ Blocks } & \multirow{2}{*}{\multicolumn{2}{|c|}{ Genotype F Values }} & \multicolumn{2}{|c|}{ Seasonal means } & \multirow{2}{*}{$\begin{array}{c}\text { GxS } \\
\text { F Values }\end{array}$} & \multirow[t]{2}{*}{ Error } \\
\hline & & & & Early & Late & & \\
\hline Days to $50 \%$ flowering & 12.12 & $56.02^{* *}$ & $14421.68 * *$ & 99.31 & 79.71 & $30.01^{* *}$ & 10.68 \\
\hline Number of leaves at flowering & 163.03 & $192.24 * *$ & $6383.08^{* *}$ & 39.90 & 26.93 & $35.99 * *$ & 71.40 \\
\hline Plant height at flowering $(\mathrm{cm})$ & 14.06 & $1236.81^{* *}$ & $17517.82^{* *}$ & 98.33 & 76.61 & $265.38^{* *}$ & 21.91 \\
\hline Final plant height $(\mathrm{cm})$ & 53.04 & $2558.06^{* *}$ & $6694.70^{* *}$ & 175.11 & 161.72 & $1868.83^{* *}$ & 31.88 \\
\hline Number of branches per plant & 0.02 & $12.82 * *$ & $42.77^{* *}$ & 3.24 & 2.24 & $4.47^{* *}$ & 0.11 \\
\hline Number of pods per branch & 12.34 & $24.68 * *$ & 19.51 & 4.81 & 4.13 & 2.83 & 7.59 \\
\hline Number of pods at stem & 0.06 & $13.32^{* *}$ & $80.67^{* *}$ & 5.60 & 4.11 & $2.42^{* *}$ & 0.11 \\
\hline Number of pods per plant & 0.43 & $40.16^{* *}$ & $68.81^{* *}$ & 10.42 & 8.24 & $16.26^{* *}$ & 0.62 \\
\hline Number of ridges per pod & 0.04 & $2.46^{* *}$ & $24.16^{* *}$ & 8.93 & 8.22 & $0.41^{* *}$ & 0.10 \\
\hline Number of seeds per ridge & 0.08 & $5.42 * *$ & $24.56 * *$ & 9.31 & 8.53 & $1.90 *$ & 0.13 \\
\hline Number of seed per pod & 5.75 & $945.48 * *$ & $3894.13^{* *}$ & 83.06 & 69.31 & $69.58 * *$ & 10.75 \\
\hline 250 Seed weight (g) & 0.26 & $7.63^{* *}$ & $2.59^{* *}$ & 13.64 & 13.30 & 0.20 & 0.17 \\
\hline Pod length $(\mathrm{cm})$ & 0.17 & $10.47^{* *}$ & $47.26^{* *}$ & 9.71 & 6.81 & 2.40 & 0.20 \\
\hline Pod breadth $(\mathrm{cm})$ & 0.18 & $6.17^{* *}$ & $41.82^{* *}$ & 11.01 & 10.04 & 0.73 & 0.92 \\
\hline Seed weight per plant (g) & 0.44 & $212.97^{* *}$ & $42.27 * *$ & 18.1 & 17.0 & $11.01^{* *}$ & 2.59 \\
\hline Pod yield per plant (g) & 5.19 & $1495.17^{* *}$ & $4837.09^{* *}$ & 48.52 & 37.12 & $80.85^{* *}$ & 812.31 \\
\hline
\end{tabular}

${ }^{*} \mathrm{P}<0.05,{ }^{* *} \mathrm{P}<0.01$. Degree of freedom: Block, 2; Genotype, 24; Season, 1; GxS, Genotype x Season, 24; Error, 98.

Table 4. Mean of measured traits in studied 25 varieties of West African okra using Duncan multiple range test for mean comparison in the early planting season.

\begin{tabular}{|c|c|c|c|c|c|c|c|c|c|c|c|c|c|c|c|c|}
\hline Accessions & $\begin{array}{c}\text { d } \\
50 \% \\
\text { flo }\end{array}$ & $\begin{array}{c}\text { Leaves } \\
50 \%\end{array}$ & $\begin{array}{c}\text { Height } \\
50 \%\end{array}$ & $\begin{array}{c}\text { Final } \\
\text { plt } \\
\text { hei }\end{array}$ & $\begin{array}{c}\text { no } \\
\text { bra/plt }\end{array}$ & $\begin{array}{l}\text { Pods/ } \\
\text { bra }\end{array}$ & $\begin{array}{l}\text { Pods/ } \\
\text { stem }\end{array}$ & $\begin{array}{c}\text { Pods/ } \\
\text { plt }\end{array}$ & $\begin{array}{l}\text { Rid/ } \\
\text { pod }\end{array}$ & $\begin{array}{l}\text { Seed/ } \\
\text { ridge }\end{array}$ & $\begin{array}{c}\text { Seed/ } \\
\text { pod }\end{array}$ & $\begin{array}{c}250 \\
\text { se wt } \\
(g)\end{array}$ & $\begin{array}{l}\text { Pod } \\
\text { length } \\
(\mathrm{cm})\end{array}$ & $\begin{array}{l}\text { Pod } \\
\text { breadth } \\
(\mathrm{cm})\end{array}$ & $\begin{array}{l}\text { Seed } \\
\text { wt/ } \\
\text { Plt }\end{array}$ & $\begin{array}{c}\text { Pod yield/ } \\
\text { PLT } \\
\text { (g) }\end{array}$ \\
\hline CEN 010 & $98.3^{\mathrm{b}-\mathrm{d}}$ & $44.6^{\mathrm{ab}}$ & $94.6^{\text {gh }}$ & $193.0^{\mathrm{d}}$ & $6.5^{\mathrm{a}}$ & $6.2^{\mathrm{a}-\mathrm{d}}$ & 6.0 cde & $12.2^{\mathrm{a}-\mathrm{f}}$ & $9.3^{b c}$ & $9.1^{\mathrm{cd}}$ & $85.6^{\mathrm{efg}}$ & $14.1^{\text {cde }}$ & $11.6^{b}$ & $9.2^{\mathrm{f}}$ & $23.1^{\text {b-e }}$ & $79.8^{\mathrm{a}}$ \\
\hline NGAE-96-012-2 & 95.9 de & $55.3^{\mathrm{a}}$ & $106.4^{\mathrm{de}}$ & $180.0^{g}$ & $5.1^{\mathrm{bc}}$ & $7.8^{\mathrm{abc}}$ & $6.8^{\mathrm{b}}$ & $14.2^{2 \mathrm{abc}}$ & $9.1^{\mathrm{b}-\mathrm{e}}$ & $9.3^{\mathrm{c}}$ & $84.5^{\text {efg }}$ & $13.2^{\text {gh }}$ & $9.7^{-f}$ & $11.0^{\mathrm{b}-\mathrm{f}}$ & $14.3^{\mathrm{gh}}$ & $56.0^{\mathrm{f}}$ \\
\hline NGAE-96-012-3 & $96.2^{c-e}$ & $38.2^{2 \mathrm{~b}}$ & $88.2^{\text {hij }}$ & $149.2^{\mathrm{i}}$ & $6.2^{\mathrm{a}}$ & $3.3^{\mathrm{a}-\mathrm{d}}$ & $5.3^{\mathrm{fg}}$ & $7.8^{\mathrm{b}-\mathrm{g}}$ & $8.6^{\mathrm{d}-\mathrm{h}}$ & $9.6^{c}$ & $82.2^{\mathrm{efg}}$ & $13.5^{\text {efg }}$ & $10.2^{\text {cde }}$ & $11.1^{b-f}$ & $14.4^{\mathrm{fgh}}$ & $34.9^{1}$ \\
\hline CEN 016 & $99.6^{a-d}$ & $39.8^{\mathrm{ab}}$ & $75.7^{1 \mathrm{~m}}$ & $186.5^{\mathrm{ef}}$ & $1.5^{\mathrm{k}}$ & $1.0^{\mathrm{cd}}$ & $3.4^{\mathrm{k}}$ & $4.5^{\mathrm{g}}$ & $9.0^{b-f}$ & $10.6^{b}$ & $95.4^{\mathrm{cd}}$ & $14.2^{\mathrm{bcd}}$ & $12.6^{\mathrm{a}}$ & $9.7^{\mathrm{def}}$ & $12.9^{\mathrm{h}}$ & $46.6^{\text {hi }}$ \\
\hline CEN 012 & $99.8^{\mathrm{a}-\mathrm{d}}$ & $36.3^{\mathrm{ab}}$ & $79.8^{\mathrm{j}-\mathrm{m}}$ & $174.6^{9}$ & $1.6^{\mathrm{ij}}$ & $3.6^{\mathrm{a}-\mathrm{d}}$ & $4.0^{\mathrm{ijk}}$ & $7.6^{\mathrm{d}-\mathrm{g}}$ & $8.5^{\mathrm{e}-\mathrm{h}}$ & 8.25 & $69.9 \mathrm{gij}$ & $13.4^{g}$ & $9.0^{\mathrm{g}-\mathrm{i}}$ & $11.1^{\mathrm{b}-\mathrm{f}}$ & $21.1^{c-f}$ & $76.4^{\mathrm{ab}}$ \\
\hline CEN 007 & $101.7^{\mathrm{ab}}$ & $34.6^{\mathrm{b}}$ & $107.1^{\text {cde }}$ & $186.3^{f}$ & $0.9^{\mathrm{ko}}$ & $3.6^{\mathrm{a}-\mathrm{d}}$ & $3.8^{\mathrm{jk}}$ & $7.4^{\mathrm{d}-\mathrm{g}}$ & $9.4^{b}$ & $8.4^{\mathrm{ef}}$ & $79.2^{\mathrm{fgh}}$ & $13.3^{\mathrm{g}}$ & $7.4^{\mathrm{k}}$ & $11.7^{\mathrm{bcd}}$ & $14.3^{\mathrm{fgh}}$ & $41.4 \mathrm{jk}$ \\
\hline NGAE-96-04 & $98.3^{b-d}$ & $44.1^{1 \mathrm{ab}}$ & $96.1^{\text {fgh }}$ & $200.9^{c}$ & $2.5^{f g}$ & $7.5^{\mathrm{abc}}$ & $5.5^{\mathrm{ef}}$ & $13.0^{a-e}$ & $10.1^{\mathrm{a}}$ & $10.6^{b}$ & $107.1^{\mathrm{a}}$ & $14.4^{\mathrm{bc}}$ & $11.8^{\mathrm{ab}}$ & $12.0^{\mathrm{bc}}$ & $29.9^{a b}$ & $76.0^{\mathrm{b}}$ \\
\hline CEN-015 & $98.5^{b-d}$ & $40.8^{a b}$ & 84.9ijk & $129.3^{k}$ & $4.4^{\mathrm{d}}$ & $6.4^{\mathrm{a}-\mathrm{d}}$ & $6.1^{\mathrm{bcd}}$ & $12.5^{\mathrm{a}-\mathrm{f}}$ & $9.3^{b c}$ & $10.7^{b}$ & $100.3^{3 a b c}$ & $14.2^{\mathrm{bcd}}$ & $10.0^{\text {cde }}$ & $11 . g^{\mathrm{gcd}}$ & $13.2^{\mathrm{gh}}$ & $48.8^{\text {gh }}$ \\
\hline OAA96/175-5328 & $100.3^{\mathrm{ab}}$ & $44.8^{\mathrm{ab}}$ & $72.0^{\mathrm{m}}$ & $137.9^{j}$ & $0.7^{1}$ & $0.7^{\mathrm{d}}$ & $4.4^{\mathrm{hij}}$ & $5.1^{g}$ & $9.1^{b c d}$ & $6.6^{g}$ & $60.6^{\mathrm{kl}}$ & $14.0^{c-f}$ & $8.2^{i \mathrm{jk}}$ & $10.3^{c-f}$ & $13.4^{\mathrm{gh}}$ & $18.4^{\circ}$ \\
\hline AGA97/066-5780 & $98.8^{b-d}$ & $29.3^{b}$ & $93.2^{\text {ghi }}$ & $200.7^{c}$ & $5.4^{\mathrm{b}}$ & $9.7^{\mathrm{a}}$ & $6.6^{b c}$ & $16.4^{\mathrm{a}}$ & $10.0^{\mathrm{a}}$ & $7.9^{f}$ & $79.3^{\mathrm{fgh}}$ & $14.3^{b c}$ & $10.4^{\text {cd }}$ & $14.3^{\mathrm{a}}$ & $28.4^{\mathrm{abc}}$ & $68.5^{\mathrm{cd}}$ \\
\hline ADO-EKITI-1 & $99.7^{-\mathrm{ad}}$ & $38.1^{\mathrm{ab}}$ & $95.1^{\text {gh }}$ & $137.3^{j}$ & $2.4^{\mathrm{fg}}$ & $3.9^{\mathrm{a}-\mathrm{d}}$ & $2.5^{1}$ & $6.3^{\mathrm{efg}}$ & $7.3^{\mathrm{i}}$ & $9.2^{\mathrm{cd}}$ & $67.8 \mathrm{j}^{\mathrm{k}}$ & $13.4^{\mathrm{g}}$ & $9.4^{\mathrm{d}-\mathrm{g}}$ & $10.0^{c-f}$ & $17.7^{\mathrm{ef}}$ & $20.2^{0}$ \\
\hline CEN-001 & $100.8^{\mathrm{ab}}$ & $38.3^{3 \mathrm{~b}}$ & $120.3^{b}$ & $205.2^{\mathrm{bc}}$ & $1.5^{\mathrm{k}}$ & $5.7^{\mathrm{a}-\mathrm{d}}$ & $6.5^{\mathrm{bcd}}$ & $12.1^{\mathrm{a}-\mathrm{f}}$ & $8.0^{\mathrm{h}}$ & $10.4^{b}$ & $82 . \mathrm{g}^{\mathrm{efg}}$ & $15.0^{\mathrm{a}}$ & $10.1^{\text {cde }}$ & $11.1^{\mathrm{b}-\mathrm{f}}$ & $15.6^{\mathrm{fg}}$ & $29.6^{\mathrm{n}}$ \\
\hline CEN-009 & $99.9^{\mathrm{a}-\mathrm{d}}$ & $47.4^{\mathrm{ab}}$ & $142.2^{\mathrm{a}}$ & 191.0def & $6.8^{\mathrm{a}}$ & $3.7^{\mathrm{a}-\mathrm{d}}$ & $2.3^{\mathrm{l}}$ & $5.9^{\mathrm{fg}}$ & $8.6^{\mathrm{e}-\mathrm{g}}$ & $10.3^{b}$ & $88.8^{\mathrm{de}}$ & $11.9 \mathrm{j}$ & $9.9 c-f$ & $9.9 c-f$ & $13.5^{\mathrm{gh}}$ & $44.6^{\mathrm{ij}}$ \\
\hline NGAE-96-0062-2 & $100.9^{\mathrm{ab}}$ & $47.2^{2 \mathrm{~b}}$ & $93.1^{\text {ghi }}$ & $130.4^{\mathrm{k}}$ & $5.2^{b}$ & $3.4^{\mathrm{a}-\mathrm{d}}$ & $4.2^{\mathrm{hij}}$ & $7.6^{\mathrm{d}-\mathrm{g}}$ & $8.3^{\text {gh }}$ & $9.5^{\mathrm{c}}$ & $79.1^{\mathrm{fgh}}$ & $14.0^{c-f}$ & $9.3^{\mathrm{e}-\mathrm{h}}$ & $10.0^{c-f}$ & $12.7^{\mathrm{h}}$ & $28.5^{\mathrm{n}}$ \\
\hline NGAE-96-0066 & $98.4^{\mathrm{b}-\mathrm{d}}$ & $39.1^{1 \mathrm{ab}}$ & $120.6^{b}$ & $210.2^{b}$ & $3.8 \mathrm{e}$ & $3.2^{\mathrm{a}-\mathrm{d}}$ & $4.6^{\mathrm{hi}}$ & $7.8^{c-g}$ & $9.4^{\mathrm{b}}$ & $9.2^{\mathrm{cd}}$ & $86.6^{\mathrm{def}}$ & $13.5^{\mathrm{fg}}$ & $8.5^{\mathrm{hij}}$ & $11.3^{\mathrm{b}-\mathrm{f}}$ & $14.5^{\mathrm{fgh}}$ & $58.3^{\mathrm{f}}$ \\
\hline NGAE-96-0061 & $100.9^{\mathrm{ab}}$ & $44.7^{\mathrm{ab}}$ & $94.8^{\text {gh }}$ & $188.7^{\text {def }}$ & $2.3^{g}$ & $2.2^{\mathrm{bcd}}$ & $5.8^{\text {def }}$ & $8.0^{c-g}$ & $9.3^{\mathrm{bc}}$ & $9.5^{c}$ & $88.5^{\text {de }}$ & $11.4^{\mathrm{k}}$ & $7.9^{\mathrm{jk}}$ & $11.6^{\mathrm{b}-\mathrm{e}}$ & $16.8^{\text {efg }}$ & $30.5^{\mathrm{mn}}$ \\
\hline NGAE-96-0060 & $98.5^{b-d}$ & $38.2^{2 \mathrm{~b}}$ & $82.5^{\mathrm{jkl}}$ & $192.5^{\mathrm{de}}$ & $3.5^{\mathrm{e}}$ & $5.3^{\mathrm{a}-\mathrm{d}}$ & $4.8^{\mathrm{ghh}}$ & $10.1^{a-g}$ & $8.4^{\mathrm{fgh}}$ & $10.4^{b}$ & $88.0^{\mathrm{de}}$ & $13.3^{3 h}$ & $12.2^{\mathrm{ab}}$ & $9.7^{\mathrm{def}}$ & $32.1^{\mathrm{a}}$ & $70.7^{c}$ \\
\hline NGAE-96-0064 & $98.6^{b-d}$ & $33.7^{\mathrm{b}}$ & $99.4^{\mathrm{efg}}$ & $179.7^{\mathrm{g}}$ & $1.4^{\mathrm{j}}$ & $2.8^{\mathrm{bcd}}$ & $6.6^{b c}$ & $9.5^{a-g}$ & $8.6^{\mathrm{e}-\mathrm{g}}$ & $9.5^{c}$ & $81.7^{\text {efg }}$ & $12.5^{\mathrm{i}}$ & $8.4^{\mathrm{ij}}$ & $11.4^{\mathrm{b}-\mathrm{f}}$ & $18.7^{\mathrm{def}}$ & $34.1^{1 \mathrm{~m}}$ \\
\hline NGAE-96-0063 & $99.5^{a-d}$ & $30.2^{\mathrm{b}}$ & $120.4^{b}$ & $179.4^{g}$ & $1.3^{\mathrm{k}}$ & $6.2^{\mathrm{a}-\mathrm{d}}$ & $8.9^{\mathrm{a}}$ & $15.2^{\mathrm{ab}}$ & $9.1^{\mathrm{bcd}}$ & $11.5^{\mathrm{a}}$ & $105.4^{\mathrm{ab}}$ & $14.7^{7 \mathrm{~b}}$ & $10.0^{\text {cde }}$ & $12.7^{\mathrm{ab}}$ & $29.3^{3 \mathrm{~b}}$ & $65.7^{\mathrm{d}}$ \\
\hline CEN 005 & $99.0^{a-d}$ & $35.3^{\mathrm{b}}$ & $105.2^{\mathrm{de}}$ & $162.4^{\mathrm{h}}$ & $2.1^{\text {ghi }}$ & $2.8^{\mathrm{bcd}}$ & $9.0^{\mathrm{a}}$ & $11 . .^{a-f}$ & $8.5^{\mathrm{e}-\mathrm{h}}$ & $8.6^{\mathrm{def}}$ & $72.8^{\text {hij }}$ & $15.2^{\mathrm{a}}$ & $10.5^{c}$ & $12.1^{\mathrm{bc}}$ & $15.9^{\mathrm{fg}}$ & $51.2^{\mathrm{g}}$ \\
\hline NGAE-96-0065 & $99.8^{8-d}$ & $38.3^{\mathrm{ab}}$ & $112.6^{\mathrm{bcd}}$ & $161.5^{\mathrm{h}}$ & $1.6^{\mathrm{ghi}}$ & $7.1^{a-d}$ & $6.5^{\mathrm{bc}}$ & $13.7^{-\mathrm{ad}}$ & $8.5^{\mathrm{e}-\mathrm{h}}$ & $9.3^{\text {cd }}$ & $79.1^{\mathrm{fgh}}$ & $12.8^{\text {hi }}$ & $8.7^{6-j}$ & $11.7^{\mathrm{bcd}}$ & $13.8^{g h}$ & $48.6^{\text {gh }}$ \\
\hline OJA OBA-2 & $103.0^{\mathrm{a}}$ & $38.1^{a b}$ & $115.0^{\mathrm{bc}}$ & $222.8^{\mathrm{a}}$ & $4.5^{\mathrm{d}}$ & $7.3^{a-d}$ & $6.2^{\text {bcd }}$ & $13.5^{a-d}$ & $9.3^{\mathrm{bc}}$ & $10.5^{b}$ & $98.7^{\mathrm{bc}}$ & $15.1^{\mathrm{a}}$ & $9.8^{c-f}$ & $11.0^{b-f}$ & $15.0^{\mathrm{fg}}$ & $50.5^{g}$ \\
\hline OJA OBA-3 & $100.0^{\mathrm{abc}}$ & $43.6^{\mathrm{ab}}$ & $78.7^{\mathrm{klm}}$ & $165.9^{\mathrm{h}}$ & $2.9^{f}$ & $8.1^{a b}$ & $5.4^{\text {efg }}$ & $13.5^{a-d}$ & $9.3^{\mathrm{bc}}$ & $8.3^{f}$ & $77.1^{\text {ghi }}$ & $13.3^{g}$ & $9.5^{\mathrm{d}-\mathrm{g}}$ & $9.3^{\mathrm{ef}}$ & $16.2^{\text {efg }}$ & $38.8^{k}$ \\
\hline ADO-EKITI-3 & $94.5^{\mathrm{e}}$ & $34.4^{\mathrm{b}}$ & $74.1^{1 \mathrm{~m}}$ & $132.6^{\mathrm{jk}}$ & $2.2^{\text {gh }}$ & $1.7^{\mathrm{bcd}}$ & $5.4^{\mathrm{efg}}$ & $7.1^{\mathrm{d}-\mathrm{g}}$ & $8.7^{c-g}$ & $9.1^{\text {cde }}$ & $79.2^{\mathrm{fgh}}$ & $10.8^{1}$ & $8.4^{i j}$ & $11.4^{\mathrm{b}-\mathrm{f}}$ & $14.2^{\text {gh }}$ & $32.2^{1 \mathrm{mn}}$ \\
\hline NGAE-96-0067 & $100.7^{\mathrm{ab}}$ & $42.3^{\mathrm{ab}}$ & $104.1^{\mathrm{def}}$ & $178.5^{g}$ & $4.6^{c \mathrm{~cd}}$ & $6.7^{-\mathrm{d} d}$ & $8.5^{\mathrm{a}}$ & $15.2^{\mathrm{ab}}$ & $10.0^{\mathrm{a}}$ & $5.6^{\mathrm{h}}$ & $56.2^{1}$ & $13.7^{\mathrm{d}-\mathrm{g}}$ & $9.6^{c-g}$ & $10.3^{c-f}$ & $21.1^{1-f}$ & $62.1^{\mathrm{e}}$ \\
\hline
\end{tabular}


Table 5. Mean of measured traits in studied 25 varieties of West African okra using Duncan multiple range test for mean comparison in the late planting season.

\begin{tabular}{|c|c|c|c|c|c|c|c|c|c|c|c|c|c|c|c|c|}
\hline Accessions & $\begin{array}{c}d \\
50 \% \\
\text { flo }\end{array}$ & $\begin{array}{c}\text { Leaves } \\
\mathbf{5 0 \%}\end{array}$ & $\begin{array}{c}\text { Height } \\
50 \%\end{array}$ & $\begin{array}{l}\text { Final } \\
\text { plt } \\
\text { hei }\end{array}$ & $\begin{array}{c}\text { no } \\
\text { bra/plt }\end{array}$ & $\begin{array}{l}\text { Pods/ } \\
\text { bra }\end{array}$ & $\begin{array}{l}\text { Pods/ } \\
\text { stem }\end{array}$ & $\begin{array}{l}\text { Pods/ } \\
\text { plt }\end{array}$ & $\begin{array}{l}\text { Rid/ } \\
\text { pod }\end{array}$ & $\begin{array}{l}\text { Seed/ } \\
\text { ridge }\end{array}$ & $\begin{array}{c}\text { Seed/ } \\
\text { pod }\end{array}$ & $\begin{array}{c}250 \\
\text { se wt } \\
(g)\end{array}$ & $\begin{array}{l}\text { Pod } \\
\text { length } \\
(\mathrm{cm})\end{array}$ & $\begin{array}{l}\text { Pod } \\
\text { breadth } \\
\text { (cm) }\end{array}$ & $\begin{array}{l}\text { Seed } \\
\text { wt/ } \\
\text { Plt }\end{array}$ & $\begin{array}{c}\text { Pod yield/ } \\
\text { PLT } \\
\text { (g) }\end{array}$ \\
\hline CEN 010 & $78 . .^{a-f}$ & $26.8^{b-f}$ & $76.4^{\text {def }}$ & $182.8^{b c}$ & $3.5^{c}$ & $4.2^{\mathrm{a}-\mathrm{e}}$ & $3.1^{1 \mathrm{jk}}$ & $7.3^{c-g}$ & $7.5^{\mathrm{hij}}$ & $8.3^{c}$ & $62.3^{j \mathrm{kl}}$ & $14.0^{\mathrm{bcd}}$ & $9.6^{\mathrm{bcd}}$ & $8.4^{\mathrm{h}}$ & $17.7^{\mathrm{f}}$ & $51.3^{\mathrm{cd}}$ \\
\hline NGAE-96-012-2 & $72 . \mathrm{e}^{\mathrm{efg}}$ & $38.1^{\mathrm{ab}}$ & $85.2^{\mathrm{bc}}$ & $123.6^{\mathrm{i}}$ & $4.3^{b}$ & $6.3^{\mathrm{abc}}$ & $4.7^{\mathrm{ef}}$ & $11.0^{\mathrm{ab}}$ & $8.8^{b c}$ & $8.3^{c}$ & $73.0^{\mathrm{d}-\mathrm{g}}$ & $13.1^{c-f}$ & $10.2^{b}$ & $9.9^{c-g}$ & $13.4^{\mathrm{ghi}}$ & $41.4^{\mathrm{efg}}$ \\
\hline NGAE-96-012-3 & $84.8^{a b c}$ & $25.8^{b-f}$ & $59.7^{\mathrm{hji}}$ & $140^{\mathrm{gh}}$ & $4.6^{\mathrm{b}}$ & $3.4^{\text {cde }}$ & $3.5^{\mathrm{hij}}$ & $6.9 \mathrm{~d}-\mathrm{g}$ & $7.6^{\mathrm{hi}}$ & $8.6^{\mathrm{bc}}$ & $65.4^{\mathrm{h}-\mathrm{k}}$ & $13.2^{c-f}$ & $10.0^{\mathrm{bc}}$ & $9.9^{c-g}$ & $13.5^{\text {ghi }}$ & $22.9 \mathrm{j}$ \\
\hline CEN 016 & $78.0^{c-f}$ & $26.4^{\mathrm{b}-\mathrm{f}}$ & $56.3^{j}$ & $161.8^{\mathrm{ef}}$ & $3.6^{\mathrm{c}}$ & $1.7^{\mathrm{e}}$ & $5.2^{\mathrm{d}}$ & $6.9^{\mathrm{d}-\mathrm{g}}$ & $7.6^{\mathrm{hi}}$ & $9.5^{\mathrm{a}}$ & $72.1^{\mathrm{e}-\mathrm{h}}$ & $14.0^{\mathrm{bcd}}$ & $11.4^{\mathrm{a}}$ & $9.5^{\mathrm{d}-\mathrm{h}}$ & $14.2^{\mathrm{gh}}$ & $40.4^{\text {efg }}$ \\
\hline CEN 012 & $69.5^{g}$ & $27.7^{\mathrm{b}-\mathrm{f}}$ & $84.5^{\mathrm{bcd}}$ & $144.7^{\mathrm{g}}$ & $4.8^{\mathrm{ab}}$ & $2.0^{\mathrm{de}}$ & $2.3^{\mathrm{m}}$ & $4.4^{g}$ & $6.6^{\mathrm{k}}$ & $7.6^{\mathrm{d}}$ & $50.4^{\mathrm{no}}$ & $13.0^{\mathrm{ef}}$ & $8.4^{\mathrm{fg}}$ & $10.1^{b-f}$ & $17.4^{\mathrm{fg}}$ & $52.5^{\mathrm{bc}}$ \\
\hline CEN-001 & $84.6^{\mathrm{abc}}$ & 19. $\mathrm{ef}^{\mathrm{ef}}$ & $89.3^{\mathrm{ab}}$ & $157^{f}$ & $1.1^{\mathrm{f}-\mathrm{i}}$ & $3.5^{\text {cde }}$ & $4.4^{\mathrm{fg}}$ & $7.9^{b-g}$ & $8.1^{\mathrm{efg}}$ & $8.6^{\mathrm{bc}}$ & $70.2^{g-i}$ & $13.0^{\mathrm{ef}}$ & $6.5^{\mathrm{jk}}$ & $10.9^{\text {a-d }}$ & $13.7^{\text {ghi }}$ & $29.2^{\mathrm{i}}$ \\
\hline NGAE-96-04 & $73.2^{\text {efg }}$ & $34.6^{\mathrm{abc}}$ & $64.6^{\text {ghi }}$ & $181.5^{\mathrm{bc}}$ & $1.7 \mathrm{de}$ & $5.4^{\mathrm{a}-\mathrm{e}}$ & $3.1^{\mathrm{jk}}$ & $8.5^{\mathrm{b}-\mathrm{f}}$ & $9.3^{\mathrm{a}}$ & $9.0^{\mathrm{ab}}$ & $85.0^{\mathrm{a}}$ & $14.0^{\mathrm{bcd}}$ & $6.6 \mathrm{j}^{\mathrm{k}}$ & $11.5^{\mathrm{ab}}$ & $32.8^{\mathrm{a}}$ & $63.8^{\mathrm{a}}$ \\
\hline CEN-015 & $73.6^{\mathrm{efg}}$ & $18.2^{f}$ & $57.2^{\mathrm{ji}}$ & $186.4^{b}$ & $1.2^{\mathrm{e}-\mathrm{i}}$ & $7.4^{\mathrm{ab}}$ & $3.7^{\mathrm{hi}}$ & $11.1^{\mathrm{ab}}$ & $8.3^{c-f}$ & $9.4^{\mathrm{a}}$ & $78 .^{4-\mathrm{e}}$ & $14.1^{b c}$ & $11.5^{\mathrm{a}}$ & $11.0^{\mathrm{abc}}$ & $12.8^{\mathrm{ij}}$ & $42.8^{\mathrm{ef}}$ \\
\hline OAА96/175-5328 & $84.2^{\mathrm{a}-\mathrm{d}}$ & $25.6^{\mathrm{b}-\mathrm{f}}$ & $37.8^{\mathrm{k}}$ & $118.1^{\mathrm{i}}$ & $0.7^{\mathrm{i}}$ & $1.8^{\mathrm{de}}$ & $2.9^{\mathrm{kl}}$ & $4.8^{g}$ & $8.4^{c-e}$ & $6.6^{\mathrm{e}}$ & $55.6^{\mathrm{mno}}$ & $13.7^{\mathrm{b}-\mathrm{e}}$ & $6.5 \mathrm{jk}^{\mathrm{k}}$ & $9.4^{\mathrm{e}-\mathrm{h}}$ & $14.7^{\text {gh }}$ & $14.0^{\mathrm{k}}$ \\
\hline AGA97/066-5780 & $71.3^{\mathrm{fg}}$ & $32.6^{\mathrm{a}-\mathrm{e}}$ & $66.6^{\text {sh }}$ & $181.8^{b c}$ & $5.3^{\mathrm{a}}$ & $7.6^{\mathrm{a}}$ & $5.0^{\mathrm{de}}$ & $12.6^{\mathrm{a}}$ & $9.6^{\mathrm{a}}$ & $8.5^{\mathrm{bc}}$ & $82.6^{\text {ab }}$ & $14.3^{\mathrm{ab}}$ & $7.9^{\mathrm{gh}}$ & $10.3^{b-f}$ & $25.0^{\text {cde }}$ & $59.5^{\mathrm{a}}$ \\
\hline ADO-EKITI-1 & $76.4^{\mathrm{d}-\mathrm{g}}$ & $24.5^{b-f}$ & $70.4 \mathrm{fg}$ & $180.3^{\mathrm{bcd}}$ & $1.9^{\mathrm{d}}$ & $3.8^{\mathrm{b}-\mathrm{e}}$ & $1.7^{\mathrm{n}}$ & $5.5^{\mathrm{fg}}$ & $6.9 \mathrm{jk}$ & $8.4^{c}$ & $58.7 \mathrm{~km}$ & $14.0^{\mathrm{bcd}}$ & $8.7^{\mathrm{ef}}$ & $9.3^{\mathrm{e}-\mathrm{h}}$ & $13.1^{\mathrm{hij}}$ & $21.0^{\mathrm{j}}$ \\
\hline CEN 001 & $83.0^{a-d}$ & $25.6^{\mathrm{b}-\mathrm{f}}$ & $90.2^{2 \mathrm{~b}}$ & $193.2^{\mathrm{b}}$ & $1.7^{\text {edf }}$ & $7.6^{\mathrm{a}}$ & $4.6^{\mathrm{ef}}$ & $12.3^{\mathrm{a}}$ & $7.0^{\mathrm{ijk}}$ & $9.2^{\mathrm{a}}$ & $65.3^{\mathrm{h}-\mathrm{k}}$ & $15.0^{\mathrm{a}}$ & $9.6^{\mathrm{bcd}}$ & $10.0^{c-g}$ & $12.0^{\mathrm{j}}$ & $22.4 \mathrm{j}$ \\
\hline CEN-009 & $83.7^{7-d}$ & $37.7^{\mathrm{ab}}$ & $87.5^{\text {ab }}$ & $190.3^{b}$ & $4.7^{7^{a b}}$ & $4.6^{\mathrm{a}-\mathrm{e}}$ & $1.2^{0}$ & $5.8^{\mathrm{efg}}$ & $7.9^{\mathrm{fgh}}$ & $8.1^{\mathrm{cd}}$ & $64.0^{\mathrm{h}-\mathrm{k}}$ & $10.7^{\mathrm{h}}$ & $7.4^{\mathrm{hi}}$ & $8.6^{\text {gh }}$ & $13.1^{\mathrm{hij}}$ & $36.7^{\mathrm{fg}}$ \\
\hline NGAE-96-0062-2 & $82.5^{\mathrm{a}-\mathrm{d}}$ & $41.6^{\mathrm{a}}$ & $75.1^{\mathrm{f}}$ & $205.1^{\mathrm{a}}$ & $0.7^{\mathrm{i}}$ & $2.6^{\mathrm{de}}$ & $3.2^{2 \mathrm{jk}}$ & $5.8^{\mathrm{efg}}$ & $7.5^{\text {hij }}$ & $6.6^{\mathrm{e}}$ & $49.4^{\circ}$ & $12 . \mathrm{g}^{\mathrm{ef}}$ & $7.8^{\mathrm{gh}}$ & $9.0^{\mathrm{fgh}}$ & $13.2^{\mathrm{hij}}$ & $23.6^{\mathrm{ij}}$ \\
\hline NGAE-96-0066 & $78.2^{c-f}$ & $27.8^{b-f}$ & $96.2^{\mathrm{a}}$ & $189.6^{\mathrm{b}}$ & $1.0^{-\mathrm{i}}$ & $3.1^{\text {cde }}$ & $6.0^{\mathrm{b}}$ & $9.1^{\mathrm{a}-\mathrm{f}}$ & $8.4^{c-e}$ & $9.4^{\mathrm{a}}$ & $79.3^{a-d}$ & $13.1^{\text {def }}$ & $5.9^{\mathrm{k}}$ & $9.6^{c-h}$ & $13.7^{\mathrm{ghi}}$ & $35.5^{\mathrm{fg}}$ \\
\hline NGAE-96-0061 & $86.7^{\mathrm{a}}$ & $33.5^{\mathrm{a}-\mathrm{d}}$ & $83.6^{\text {cde }}$ & $130.4^{\mathrm{hi}}$ & $1.1^{-\mathrm{gi}}$ & $2.6^{\mathrm{de}}$ & $3.6^{\mathrm{hij}}$ & $6.2^{\mathrm{efg}}$ & $8.4^{c-e}$ & $8.5^{\mathrm{bc}}$ & $71.8^{\mathrm{e}-\mathrm{h}}$ & $11.0^{\mathrm{h}}$ & $7.2^{\mathrm{ji}}$ & $10.9^{\mathrm{a}-\mathrm{d}}$ & $13.8^{\text {hij }}$ & $22.1^{j}$ \\
\hline NGAE-96-0060 & $78.4^{a-f}$ & $24.4^{b-f}$ & $88 . .^{a b}$ & $168.2^{\text {def }}$ & $1.4^{\mathrm{d}-\mathrm{h}}$ & $3.8^{\text {b-e }}$ & $2.5^{\mathrm{Im}}$ & $6.4^{\mathrm{efg}}$ & $8.3^{c-f}$ & $8.3^{c}$ & $68.9^{g-j}$ & $13.1^{\text {def }}$ & $11.0^{\mathrm{a}}$ & $9.1^{\text {fgh }}$ & $29.6^{\mathrm{b}}$ & $58.1^{\mathrm{ab}}$ \\
\hline NGAE-96-0064 & $83.1^{1-d}$ & $15.3^{f}$ & $88.1^{1 \mathrm{ab}}$ & $141.5^{\text {gh }}$ & $1.2^{\mathrm{e}-\mathrm{i}}$ & $2.1^{\mathrm{de}}$ & $4.6^{\mathrm{ef}}$ & $6.7^{\mathrm{d}-\mathrm{g}}$ & $8.7^{\mathrm{bcd}}$ & $9.5^{\mathrm{a}}$ & $82.6^{\mathrm{ab}}$ & $12.0^{\mathrm{g}}$ & $6.5^{\mathrm{jk}}$ & $10.6^{\text {b-e }}$ & $14.7^{\mathrm{gh}}$ & $21.0^{j}$ \\
\hline NGAE-96-0063 & $86.4^{\mathrm{ab}}$ & $19.0^{\mathrm{ef}}$ & $87.8^{\mathrm{ab}}$ & $182.2^{\mathrm{bc}}$ & $1.3^{\mathrm{d}-\mathrm{i}}$ & $4.5^{\mathrm{a}-\mathrm{e}}$ & $7.0^{\mathrm{a}}$ & $11.5^{\mathrm{ab}}$ & $8.7^{\mathrm{bcd}}$ & $9.2^{\mathrm{a}}$ & $80.4^{\mathrm{abc}}$ & $13.9^{\mathrm{bcd}}$ & $9.5^{\mathrm{bcd}}$ & $12.3^{\mathrm{a}}$ & $28.1^{\mathrm{bc}}$ & $45.3^{\mathrm{de}}$ \\
\hline CEN 005 & $78.1^{\mathrm{c}-\mathrm{f}}$ & $20.9^{c-f}$ & $76.4^{\text {def }}$ & $171.4^{\text {cde }}$ & $1.3^{\mathrm{e}-\mathrm{i}}$ & $2.1^{\mathrm{de}}$ & $6.6^{\mathrm{a}}$ & $8.7^{\mathrm{b}-\mathrm{f}}$ & $8.0^{\mathrm{fgh}}$ & $7.0^{\mathrm{e}}$ & $56.3^{1 \mathrm{mn}}$ & $15.1^{\mathrm{a}}$ & $9.6^{\mathrm{bcd}}$ & $11.0^{\mathrm{abc}}$ & $16.8^{\text {fgh }}$ & $51.1^{\mathrm{cd}}$ \\
\hline NGAE-96-0065 & $83.2^{\mathrm{a}-\mathrm{d}}$ & $25.1^{b-f}$ & $78.3^{c-f}$ & $188.6^{\mathrm{b}}$ & $1.4^{\mathrm{e}-\mathrm{h}}$ & $4.7^{\mathrm{a}-\mathrm{e}}$ & $5.4^{\mathrm{cd}}$ & $10.1^{1-d}$ & $8.3^{c-f}$ & $8.4^{c}$ & $69.7^{\text {ghi }}$ & $12.8 \mathrm{fg}$ & $8.8^{\mathrm{ef}}$ & $10.6^{b-e}$ & $14.0^{\mathrm{ghi}}$ & $46.4^{\text {cde }}$ \\
\hline OJA OBA-2 & $83.4^{\mathrm{a}-\mathrm{d}}$ & $26.8^{\mathrm{b}-\mathrm{f}}$ & $88.4^{\mathrm{ab}}$ & $138.9^{\text {gh }}$ & $1.5^{\mathrm{e}-\mathrm{h}}$ & $5.0^{\mathrm{a}-\mathrm{e}}$ & $5.9^{b c}$ & $10.9^{\mathrm{abc}}$ & $8.2^{\mathrm{d}-\mathrm{g}}$ & $9.2^{\mathrm{a}}$ & $75.4^{c-g}$ & $15.1^{\mathrm{a}}$ & $9.1^{\mathrm{de}}$ & $11.7^{\mathrm{ch}}$ & $13.7^{7^{\mathrm{ghi}}}$ & $35.4^{\mathrm{gh}}$ \\
\hline OJA OBA-3 & $83.9^{\mathrm{a}-\mathrm{d}}$ & $27.4^{\mathrm{b}-\mathrm{f}}$ & $63.1^{g-j}$ & $141.6^{\text {gh }}$ & $1.4^{\mathrm{e}-\mathrm{h}}$ & $5.5^{a-d}$ & $3.8^{\text {gh }}$ & $10.9^{a-e}$ & $9.1^{\mathrm{ab}}$ & $8.4^{c}$ & $77.0^{\mathrm{b}-\mathrm{f}}$ & $13.3^{c-f}$ & $9.4^{\text {cde }}$ & $11.0^{\mathrm{h}}$ & $12.3^{\mathrm{ij}}$ & $29.5^{\mathrm{hi}}$ \\
\hline ADO-EKITI-3 & $74.3^{\mathrm{e}-\mathrm{g}}$ & $19.6^{\text {def }}$ & $75.4^{\mathrm{ef}}$ & $101.2^{j}$ & $0.9^{\text {hi }}$ & $2.4^{\mathrm{de}}$ & $3.9^{\text {gh }}$ & $6.4^{\mathrm{efg}}$ & $7.7^{\text {gh }}$ & $9.0^{\mathrm{ab}}$ & $69 . .^{\text {ghi }}$ & $10.8^{\mathrm{h}}$ & $7.8^{\text {ghi }}$ & $9.3^{c-g}$ & 13.1 hij & $17.7^{\mathrm{jk}}$ \\
\hline NGAE-96-0067 & $79.5^{\mathrm{a}-\mathrm{e}}$ & $27.6^{\mathrm{b}-\mathrm{f}}$ & $88.5^{\mathrm{ab}}$ & $141.8^{\mathrm{gh}}$ & $1.6^{\mathrm{e}-\mathrm{g}}$ & $4.0^{\mathrm{a}-\mathrm{e}}$ & $4.6^{\mathrm{ef}}$ & $8.6^{b-f}$ & $8.4^{c-e}$ & $8.1^{\text {cd }}$ & $768.6^{g-i}$ & $13.6^{\mathrm{b}-\mathrm{e}}$ & $8.2^{\mathrm{fg}}$ & $11.4^{\mathrm{e}-\mathrm{h}}$ & $28.2^{\mathrm{bc}}$ & $44.5^{\mathrm{e}}$ \\
\hline
\end{tabular}

weight of $12.0 \mathrm{~g}$. Days to $50 \%$ flowering of these genotypes ranged between 69.5 for CEN 012 to 86.7 for NGAE-96-0061. NGAE-96-0062-2 was the tallest $(205.1 \mathrm{~cm})$ and Ado-Ekiti-3 was the shortest $(101.2 \mathrm{~cm})$. The number of pods per plant varied between 4.4 for CEN 012 and 12.6 for AGA 97/066-5780. Across the seasons of evaluation, genotype NGAE96-04 with a mean pod yield of $69.9 \mathrm{~g}$ per plant was the best, followed by CEN 010 (65.6 g/plant). Among the cultivars studied, average number of days to $50 \%$ flowering was 86 days after planting. The genotypes that flowered earlier than others, Ado-Ekiti-3 (84.4 days) and CEN 012 (84.6 days), could serve as parents when breeding for early maturity because days to flowering is always correlated with life-span (Ariyo and Odulaja, 1991). Using genotypes with highest pod number per plant AGA97/066-5780 (16.4) and (12.6) in the early and late season respectively, as parents in hybridization programs may lead to considerable improvement in the pod yield. This is in agreement with the findings of Akinyele and Osekita (2006).

The progress of selection depends on knowledge of relationships of yield traits and their relative contribution, which is helpful in effective and simultaneous selection of characters (Ramesh et al., 2010). In order to reveal associations between pod yield and the other agro-morphological traits, genotypic and phenotypic correlation coefficients were calculated (Table 6). In the early season, pod yield showed the strongest positive genotypic and phenotypic correlation $\left(\mathrm{r}_{\mathrm{g}}=0.88^{* *}\right)$ $\left(\mathrm{r}_{\mathrm{p}}=0.86^{* *}\right)$ with number of pods per plant and number of pods per branch $\left(\mathrm{r}_{\mathrm{g}}=0.88^{* *}\right)\left(\mathrm{r}_{\mathrm{p}}=0.53^{* *}\right)$, followed by seed weight $\left(\mathrm{r}_{\mathrm{g}}=0.70^{* *}\right)$
Table 6. Genotypic $\left(r_{g}\right)$ and phenotypic $\left(r_{p}\right)$ correlation coefficients between pod yield (g/plant) and phonological agronomic traits for early and late planted West African okra.

\begin{tabular}{lcccc} 
Trait & \multicolumn{3}{c}{ Pod yield (g/plant) } \\
& \multicolumn{1}{c}{ Early seasons } & Late season \\
& $\mathbf{r}_{\mathrm{g}}$ & $\mathbf{r}_{\mathrm{p}}$ & $\mathbf{r}_{\mathrm{g}}$ & $\mathbf{r}_{\mathrm{p}}$ \\
Days to 50\% flowering & $-0.17 \mathrm{~ns}$ & $-0.13 \mathrm{~ns}$ & $-0.60^{* *}$ & $-0.52^{* *}$ \\
Number of leaves at flowering & $-0.47^{* *}$ & $-0.10 \mathrm{~ns}$ & $0.15 \mathrm{~ns}$ & $0.13 \mathrm{~ns}$ \\
\hline Plant height at flowering & $0.11 \mathrm{~ns}$ & $0.11 \mathrm{~ns}$ & $0.13 \mathrm{~ns}$ & $0.13 \mathrm{~ns}$ \\
Final plant height & $0.52^{* *}$ & $0.52^{* *}$ & $0.39^{* *}$ & $0.38^{* *}$ \\
\hline Number of branches per plant & $0.27^{*}$ & $0.26^{*}$ & $0.36^{* *}$ & $0.35^{* *}$ \\
Number of pods per branch & $0.88^{* *}$ & $0.53^{* *}$ & $0.39^{* *}$ & $0.31^{* *}$ \\
\hline Number of pods at stem & $0.31^{* *}$ & $0.31^{* *}$ & $0.15 \mathrm{~ns}$ & $0.15 \mathrm{~ns}$ \\
Number of pods per plant & $0.88^{* *}$ & $0.86^{* *}$ & $0.57^{* *}$ & $0.56^{* *}$ \\
\hline Number of ridges per pod & $0.51^{* *}$ & $0.48^{* *}$ & $0.32^{* *}$ & $0.38^{* *}$ \\
Number of seeds per ridge & $0.09 \mathrm{~ns}$ & $0.09 \mathrm{~ns}$ & $0.05 \mathrm{~ns}$ & $0.04 \mathrm{~ns}$ \\
\hline Number of seed per pod & $0.24^{*}$ & $0.24^{*}$ & $0.25^{*}$ & $0.24^{*}$ \\
250 seed weight & $0.29^{*}$ & $0.29^{*}$ & $0.35^{* *}$ & $0.33^{* *}$ \\
\hline Pod length & $0.52^{* *}$ & $0.51^{* *}$ & $0.29^{*}$ & $0.28^{*}$ \\
Pod breadth & $0.23 \mathrm{~ns}$ & $0.20 \mathrm{~ns}$ & $0.21 \mathrm{~ns}$ & $0.19 \mathrm{~ns}$ \\
\hline Seed weight per plant & $0.70^{* *}$ & $0.69^{* *}$ & $0.71^{* *}$ & $0.70^{* *}$
\end{tabular}

${ }^{*} \mathrm{P}<0.05 ; * * \mathrm{P}<0.01 ;$ ns, not significant. 
Table 7. Direct and indirect effects of some characters of pod yield in West African okra under early and late seasons.

\begin{tabular}{|c|c|c|c|c|c|c|c|}
\hline \multirow{2}{*}{$\begin{array}{l}\text { Early season } \\
\text { traits }\end{array}$} & \multirow{2}{*}{$\begin{array}{l}\text { Genotypic } \\
\text { correlation }\end{array}$} & \multirow{2}{*}{$\begin{array}{l}\text { Direct } \\
\text { effect }\end{array}$} & \multicolumn{5}{|c|}{ Indirect effects } \\
\hline & & & Pods/branch & Pods/ plant & Ridge/pod & Pod length & Seed weight \\
\hline Pods/branch & 0.8800 & 3.0586 & & 0.7605 & -1.4756 & -0.1176 & -1.3459 \\
\hline Pods/plant & 0.8800 & 1.0277 & 2.2633 & & -0.9152 & -0.1499 & -1.3459 \\
\hline Ridge/pod & 0.5100 & -1.8678 & 2.4163 & 0.5036 & & -0.0176 & -0.5244 \\
\hline Pod length & 0.5200 & -0.2940 & 1.2234 & 0.5241 & -0.1121 & & -0.8215 \\
\hline Seed weight & 0.7000 & -1.7479 & 2.3551 & 0.7914 & -0.5604 & -0.1382 & \\
\hline \multirow{2}{*}{$\begin{array}{l}\text { Late season } \\
\text { traits }\end{array}$} & Genotypic & Direct & \multicolumn{5}{|c|}{ Indirect effects } \\
\hline & & & Pods/branch & Pods/ plant & Ridge/pod & Pod length & Seed weight \\
\hline Pods/branch & 0.3900 & -0.2723 & & 0.5097 & -0.0339 & 0.0832 & 0.1032 \\
\hline Pods/plant & 0.5700 & 0.5927 & -0.2342 & & -0.0346 & 0.0578 & 0.1883 \\
\hline Ridge/pod & 0.3200 & -0.0706 & -0.1307 & 0.2904 & & -0.0485 & 0.2794 \\
\hline Pod length & 0.2900 & 0.2311 & -0.0980 & 0.1482 & 0.0148 & $\Delta$ & -0.0061 \\
\hline Seed weight & 0.7100 & 0.6073 & -0.0463 & 0.1837 & -0.0325 & -0.0023 & \\
\hline
\end{tabular}

Pods/branch, number of pods at branches; pods/plant, number of pods per plant; ridge/pod, number of ridges per pod; seed weight, seed weight.

$\left(\mathrm{r}_{\mathrm{p}}=0.69^{* *}\right)$, Final plant height $\left(\mathrm{r}_{\mathrm{g}}=0.52^{* *}\right)\left(\mathrm{r}_{\mathrm{g}}=0.52^{* *}\right)$, pod length $\left(\mathrm{r}_{\mathrm{g}}=0.52^{* *}\right) \quad\left(\mathrm{r}_{\mathrm{p}}=0.51^{* *}\right)$, number of ridges per pod $\left(\mathrm{r}_{\mathrm{g}}=0.51^{* *}\right)$ $\left(r_{p}=0.48^{* *}\right)$, number of pods per stem $\left(r_{g}=0.31^{* *}\right)\left(r_{p}=0.31^{* *}\right), 250$ seed weight $\left(r_{g}=0.29^{*}\right)\left(r_{p}=0.29 *\right)$ and number of branches per plant $\left(r_{g}=0.27^{*}\right)\left(r_{p}=0.26^{*}\right)$. The most significant negative genotypic correlation with pod yield was made by number of leaves at flowering ($\left.0.47^{* *}\right)\left(r_{p}=-0.10\right)$. In the late season, pod yield showed the strongest positive genotypic and phenotypic correlation $\left(\mathrm{r}_{\mathrm{g}}=0.71^{* *}\right)\left(\mathrm{r}_{\mathrm{p}}=0.70^{* *}\right)$ with seed weight per plant, followed by the number of pods per plant $\left(\mathrm{r}_{\mathrm{g}}=0.57^{* *}\right) \quad\left(\mathrm{r}_{\mathrm{p}}=0.56^{* *}\right)$, number of pods per branch $\left(\mathrm{r}_{\mathrm{g}}=0.39^{* *}\right)$ $\left(\mathrm{r}_{\mathrm{p}}=0.31^{* *}\right)$, final plant height $\left(\mathrm{r}_{\mathrm{g}}=0.39^{* *}\right) \quad\left(\mathrm{r}_{\mathrm{p}}=0.38^{* *}\right)$, number of branches per plant $\left(\mathrm{r}_{\mathrm{g}}=0.36^{* *}\right)\left(\mathrm{r}_{\mathrm{p}}=0.35^{* *}\right)$, number of ridges per pod $\left(r_{\mathrm{g}}=0.32^{* *}\right)\left(\mathrm{r}_{\mathrm{g}}=0.38^{* *}\right)$, pod length $\left(\mathrm{r}_{\mathrm{g}}=0.29^{*}\right)\left(\mathrm{r}_{\mathrm{p}}=0.28^{*}\right)$ and number of seeds per pod $\left(\mathrm{r}_{\mathrm{g}}=0.25^{*}\right)\left(\mathrm{r}_{\mathrm{p}}=0.24^{*}\right)$. Meanwhile, number of days to flowering was negatively correlated with pod yield at genotypic and phenotypic level $\left(\mathrm{r}_{\mathrm{g}}=-0.60^{* *}\right)\left(\mathrm{r}_{\mathrm{p}}=-0.52^{* *}\right)$. In some cases, differences in both magnitude and direction of correlation coefficients were observed in different seasons. Phenotypic correlation is a composite of genotypic and environmental correlations, but it was observed that genotypic correlations were, in most cases, higher than their corresponding phenotypic correlations coefficients. This has been ascribed to negative environmental correlations between the corresponding characters (Falconer and Mackay, 1996). Strong positive genotypic and phenotypic correlation coefficients between pod yield and final plant height, number of branches per plant, number of pods per branch, number of pods per plant, number of ridges per pod, weight of 250 seeds, pod length and seed weight per plant in the early and late seasons indicated that a selection based on these traits would also select plants showing a high level of pod yield. These results also corroborate previous observations (Ramya and Senhilkumar, 2009; Rashwan, 2011) that pod yield per plant was positively correlated with number of podsyer plant, pod length and number of branches per plant. The other characters may therefore not be of practical value in selecting pod yield, since selection is based on the phenotype of the characters.

Characters that are genotypically correlated but not phenotypically correlated will not be of practical value in selection since selection is often based on the phenotypical performance of the characters. This is true of the relationship between number of leaves at flowering and pod yield per plant in the early season. The association of pod yield and number of days to flowering was found to be negative and significant both at genotypic and phenotypic level in the late season. This gives a clear indication that too early maturity could lead to reduction in pod yield of West African okra cultivars, and is in agreement with similar observation of Rashwan (2011). Since pod yield did not genotypically and phenotypically correlate with days to flowering in the early season, changes from flowering to physiological maturity must have been more influential on the pod yield than the emergence to flowering period in the early season. Correlation between pod yield per plant and pod breadth was low at genotypic and phenotypic levels in the two seasons, indicating that there's good possibility of obtaining plum pods with a minimum leeway in improvement of pod yield.

The significant genotypic and phenotypic correlation between pod yield per plant and number of branches per plant and final plant height may be related to proper light interception provided by greater height and greater photosynthetic capacity provided by more leaves that are abided on the branches. Since leaves are the food manufacturing factories of the plant and the greater number of leaves assumed better crop yield due to higher photosynthetic capacity by increasing leaf area index and resultantly higher FI (fraction of intercepted radiation), intercepted PAR and its utilization efficiency. Also more branches implied more fruit bearing nodes. However, reduced days to 50\% flowering in the late season tend to increase pod yield in West African okra as it is negatively correlated to pod yield at phenotypic and genotypic levels. The insignificant association between pod yield and plant height at flowering traits in both seasons, indicated that yield improvement through direct selection of plant height at flowering as a single character would be impractical. The information derived from the correlation studies remarked only mutual association among the characters. Pod yield is sum total of the several components characters which directly or indirectly contributed to it. Whereas, path coefficient analysis helps in understanding the magnitude of direct and indirect contribution of each character on the dependant character like pod yield. Partitioning of correlation coefficient into direct and indirect effect provides the information about the nature and magnitude of effect of other characters on the pod yield. The partitioning of genotypic correlation coefficients between pod yield and each of the five independent variables for both seasons is given in Table 7 as a sum of direct and indirect effect. 
The estimates of direct and indirect effects were more pronounced in the early season than the late season. In the early season, number of pod per branch had the maximum positive direct effect (3.0586) on pod yield. This maximum direct response of this component was attributed to the indirect positive effect of the number of pods per plant. Number of pods per plant also had a high positive direct effect (1.0277), This suggests the importance and achievable success in selecting for these traits when high yield is the objective. Number of ridges per pod and seed weight per plant had the largest negative direct effect on pod yield in spite of its positive genotypic correlation with pod yield. This demonstrates the defect of selecting only on the basis of inter-character correlation as such a selection may not produce desired results. The path analysis further revealed that the adverse effect of pod length on pod yield was largely due to the indirect effects of seed weight and number of ridges per pod.

In late season okra seed weight per plant produced the greatest positive direct effect $(0.6073)$ on pod yield, closely followed by number of pods per plant (0.5927). Also pod length had a positive direct effect (0.2311) on pod yield, in spite of its low genotypic correlation. Although, number of pods per branch was still highly correlated with pod yield, its direct effect on pod yield was negative. The inconsistency observed on the direct and indirect effect of some characters on pod yield is an indication of seasonal influence on character interrelationship. It is also instructive on the need for selecting for pod yield, directly or indirectly through other characters, in a range of environments. Harris (2001) has explained how standardized path coefficients can be higher than unity in absolute value. In spite of the important pod yield related characters used in the path coefficient analysis, the residual factors were 0.5167 and 0.5410 for early and late season respectively. It predicted that 48.3 and 45.9 per cent variation in pod yield at genotypic level for early and late seasons respectively had been determined. It further portrayed the occurrence of some factors, not considered in this study, contributed to the pod yield of West African okra. This may also be due to the fact that correlation coefficients were mere estimates and to rounding-off errors.

In conclusion, West African okra varieties used in this study showed variation in pod yield performance. Genotypes CEN 010, CEN 012, NGAE-96-04 and AGA 97/066-5780 demonstrated high pod yield. In addition to this, genotype AGA 79/066-5780 had higher number of pods in the two seasons compared to other genotypes. CEN 012 is identified as early flowering and high yielding genotype which could be used in conjunction with other promising lines to develop early maturing genotypes. Despite differences in the genetic make-up of the cultivars, seasonal variability influences the ability of West African okra to compensate among yield components.

Adequate soil moisture seems a very important determinant of genotypic performance in the location. Using correlation coefficients, promising West African okra genotypes could be selected with simultaneous selection for final plant height, number of branches per plant, number of pods per branch, number of pods per plant, number of ridges per pod, weight of 250 seeds, pod length and seed weight per plant. The results from path analysis indicated that number of pods per plant had positive and direct effects on pod yield in both seasons. Indirect effect of other traits through this trait also contributed predominantly towards pod yield, indicating that selection for number of pods per plant should be the best indirect selection trait for improvement of pod yield.

However, a selection index comprising both relevant vegetative and reproductive characters would produce better results and is recommended. A balanced view of all the characters in question is of paramount importance in selecting for quantitative characters like pod yield. Subsequent research efforts should pay attention to water use potential of varieties with high yield potential. Soil fertility should also form part of subsequent evaluation of these varieties. Finally, for further improvement, sufficient crossing programs between the varieties and newly introduced germplasms may be necessary to develop dayneutral varieties, early flowering and maturing for late season-sown West African okra.

\section{References}

Adeniji OT, Aremu C0, 2007. Interrelationship among characters and path analysis for pod yield components in West African okra (Abelmoschus caillei). J. Agron. 6:162-166.

Aiboni VU, 2001. Characteristics and classification of soils of a representative topographic locationin the University of Agriculture, Abeokuta. ASSET Series A 1:51-62.

Akinyele BO, Osekita OS, 2006. Correlation and path coefficient analysis of seed yield attributes in okra (Abelmoschus esculentus (L) Moench). Afr. J. Biotechnol. 5:1330-1336.

Ariyo J0, 1993. Genetic diversity in West African okra (Abelmoschus caillei (A.Chev) Stevels-Multivariate analysis of morphological and agronomic characteristics. Genet. Resour. Crop Ev. 40:25-32.

Ariyo J0, Ayo-Vaughan M0, 2000. Analysis of genotype-environment interaction of okra (Abelmoschus esculentus). Euphytica 36:677683.

Ariyo J0, Odulaja A, 1991. Numerical analysis of variation among accessions of okra (A. esculentus (L) Moench) Malvaceae. Ann. Bot-London 67:527-531.

Condon AG, Richards RA, Rebteske GJ, Farquhar GD, 2004. Breeding for high water-use efficiency. J. Exp. Bot. 55:2447-2460.

Dewey DR, Lu KH, 1959. A correlation and path coefficient analysis of components of crested wheatgrass seed production. Agron. J. 51:515-518.

Falconer DS, Mackay TFC, 1996. Introduction to quantitative genetics, 4th ed. Longman Group Ltd., London, UK.

FAOSTAT, 2010. Statistical Database of the Food and Agriculture of the United Nations. Available from: http://www.FA0.org/site/576/ DesktopDefault.aspx? pageID=576\#ancor

Gomez KA, Gomez AA, 1984. Statistical procedures for agricultural research. John Wiley \& Sons, Metro Manila, Philippines.

Gardner FP, Peace RB, Mitchell RL, 1985. Physiology of crop plant. Iowa State University press, Ames, IA, USA.

Goldsworthy PR, 1970. The growth and yield of tall and short sorghum in Nigeria. J. Agr. Sci. 75:109-122.

Gravois KA, Helm RS, 1992. Path analysis of rice yield and yield components as affected by seeding rate. Agron. J. 84:1-4.

Grubben GJH, Denton OA, 2004. Plant resources of Tropical Africa 2 vegetables, PROTA Foundation, Wageninger, Backhus Publ., Wageningen, The Netherland.

Harris RJ, 2001. A primer of multivariate statistics, 3rd ed. Lawrence Eribaun Associate Inc., Publ., Mahwah, NJ, USA.

Kang MS, 1994. Applied quantitative genetics. M.S.Kang Publ., Baton Rouge, FL, USA.

Kempthorne 0, 1973. An introduction to genetics statistics. Iowa State University Press, Ames, IA, USA.

Loss SP, Siddique KHM, 1994. Morphological and physiological traits associated with wheat yield increases in Mediterranean environment. Adv. Agron. 52:229-276.

McGiffen ME, Pantone DJ, Masiunas JB, 1994. Path analysis of tomato yield components in relation to competition with black and eastern black nightshade. J. Am.Soc. Hortic. Sci. 119:6-11.

Miller PA, Williams JC, Robinson HF, Comstock RF, 1958. Estimates of genotypic and environmental variances in upland cotton and their implication in selection. Agron J. 50:126-131.

Olasantan FO, Salau AW, 2007. Effect of pruning on growth, leaf yield and pod yields of okra (Abelmoschus esculentus (L) Moench). J. 
Agr. 146:93-102.

Ramesh K, Sangita K, Shukla YR, 2010. Variability, correlation and path analysis studies in Lettuce. Int. J. Veg. Sci. 16:299-315.

Ramya K, Senthilkumar N, 2009. Genetic divergence, correlation and path analysis in okra (Abelmoschus esculentus). Madras Agric. J. 96:296-299.

Rashwan AMA, 2011. Study of genotypic and phenotypic correlation for some agro-economic traits in okra (Abelmoschus esculentus). Asian J. Crop. Sci. 3:85-91.

SAS, 2000. SAS/STAT statistical analysis, v.8.1. SAS Inst. Inc., Cary, NC, Usa.

Siddique AKM, Gupta SN, 1991. Genotypic and genotypic variability for seed yield and other traits in cowpea (Vigna unguiculata (L). Int. J. Trop. Agric. 9:144-148.

Shorter R, Lawn RJ, Hammer G, 1991. Improving genetic adaptation in crops- a role for breeders, physiologists and modelers. Exp. Agric. 27:155-176

Snedecor GW, Cochran WG, 1980. Statistical methods,7th ed. Iowa State University Press, Ames, Ia, USA

Sokal RR, Rohlf FJ, 1995. Biometry. The principle and practice of statistics in biological research, 3rd ed. Freeman New York, NY, USA.

Sood TS, Prem SA, Sharma SK, 1993. Correlation and path analysis in bhindi (Abelmoschus esculentus)[L] Moench). Him. J. Agric. Res. 19:32-47.

Steel RGD,Torrie JH, Dickey DA, 1997. Principle and procedures of statistics: a biometrical approach. McGraw-Hill, Columbus, OH, USA,

Wilson D,1981. Breeding for morphological and physiological traits. In: KJ Prey(ed) Plant breeding, II. Iowa state University Press, Ames, IA, USA, pp 244-299. 